
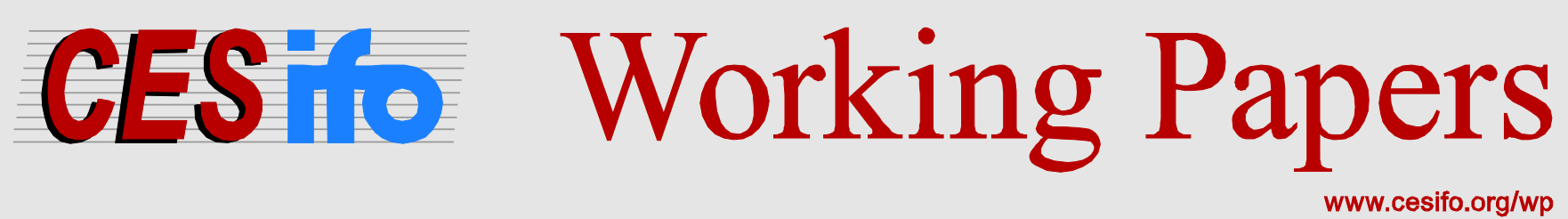

\title{
Euro Membership and Fiscal Reaction Functions
}

\author{
Alfons J. Weichenrieder \\ Jochen Zimmer
}

\section{CESIFO WORKING PAPER NO. 4255 \\ CATEgORY 1: Public FinANCE \\ MAY 2013}

An electronic version of the paper may be downloaded

- from the SSRN website:

- from the RePEc website:

- from the CESifo website:

WWW.SSRN.com

www.RePEc.org

www.CESifo-group.org/wp

\section{CESifo}




\title{
Euro Membership and Fiscal Reaction Functions
}

\begin{abstract}
The paper uses fiscal reaction functions for a panel of euro-area countries to investigate whether euro membership has reduced the responsiveness of countries to shocks in the level of inherited debt compared to the period prior to succession to the euro. While we find some evidence for such a loss in prudence, the results are not robust to changes in the specification, such as an exclusion of Greece from the panel. This suggests that the current debt problems may result to a large extent from preexisting debt levels prior to entry or from a larger need for fiscal prudence in a common currency, while an adverse change in the fiscal reaction functions for most countries does not apply.
\end{abstract}

JEL-Code: H620, E620.

Keywords: debt sustainability, fiscal reaction function, euro area.

\author{
Alfons J. Weichenrieder \\ Goethe University Frankfurt \\ Faculty of Economics and Business \\ Administration \\ Germany - 60323 Frankfurt (Main) \\ a.weichenrieder@em.uni-frankfurt.de
}

\author{
Jochen Zimmer \\ Goethe University Frankfurt \\ Faculty of Economics and Business \\ Administration \\ Germany - 60323 Frankfurt (Main) \\ jzimmer@wiwi.uni-frankfurt.de
}

10 May 2013

This paper is part of the research program of the Center "Sustainable Architecture for Finance in Europe" (S A F E). Alfons Weichenrieder is also affiliated with the University of Economics and Business, Vienna, and with CESifo. Jochen Zimmer gratefully acknowledges financial support by Hanns-Seidl-Stiftung. We are also grateful for helpful comments by participants of the CESifo Public Sector Area conference 2013. 


\section{Introduction}

The debt crisis in Europe has put renewed emphasis on the sustainability and prudence of fiscal policies. The fiscal problems of countries like Portugal and Greece, which entered the crisis with high debt levels, suggest that excessive deficits under the common currency and frequent non-compliance with the deficit limits have been major factors that contributed to the severity of the debt crisis. This view had sufficient support to bring forth a series of political activities that led to more stringent fiscal rules. Among other things, a new fiscal compact requires euro members to introduce debt brakes into national legislation, preferably at a constitutional level. While some countries started out with already high public debt, countries like Ireland and Spain had comparatively sound levels before the financial crisis and banks' balance sheet problems and public bailouts of banks have been prominent reasons for exploding public debt levels and reduced investor confidence. ${ }^{1}$

In this paper we look for evidence whether euro membership indeed has changed fiscal behavior in a systematic way making it less prudent. We do so by using panel data for European countries to estimate fiscal reaction functions. From the intertemporal budget constraint of governments a higher stock of public debt must be associated with a higher level of discounted aggregated primary surpluses in the future. While it is unclear when exactly such a reaction of the primary surplus should happen, previous studies have found significant immediate reactions (Bohn 1998, Mendoza and Ostry 2008) that document governments' efforts towards financial sustainability.

In our panel data of European countries, we compare three different time periods. We may consider the time before the signing of the Maastricht Treaty as the

\footnotetext{
${ }^{1}$ In the case of Ireland, for example, the IMF (2011) has estimated the preliminary budgetary cost of bank bailouts at $38 \%$ of GDP.
} 
period during which countries were neither influenced by a common currency, nor by the aspirations to be accepted to the common currency. In the period between the signing of the Maastricht Treaty and the start of the common currency (aspiration period), countries had to work towards the Maastricht criteria for acceptance into the European Monetary Union (EMU) and may therefore have been subject to increased fiscal responsibility. Finally, we consider the time since full membership as a separate period which is of special interest. While the stability and growth pact required continued efforts to contain government deficits, the frequent infringements of the $3 \%$-deficit rule, the weakening of the rules and the moral hazard effects from implicit bailout guarantees (i.e., a non-credible no-bailout clause) may have reduced government efforts below those of the aspiration period or even below the preMaastricht period.

Using fiscal reaction functions for a panel of actual euro-area countries the paper investigates whether euro membership has reduced the responsiveness of countries to increases in the level of inherited debt compared to the period prior to succession to the euro. While we find some evidence for such a loss in prudence, the results are not robust to changes in the specification, such as an exclusion of Greece from the panel. This suggests that the current debt problems may result to a large extent from pre-existing debt levels prior to entry or from a larger need for fiscal prudence in a common currency as an adverse change in the fiscal reaction functions for most countries does not apply.

The remainder of the paper is organized as follows. Section 2 briefly reviews the intertemporal budget constraint of the government as a starting point for the analysis of sustainability issues. Section 3 introduces the concept of the fiscal reaction functions. Section 4 provides some descriptive statistics before we present the main empirical results in section 5. Section 6 provides some conclusions. 


\section{The Sustainability of Government Debt}

The assessment of the sustainability of government finances usually starts from the intertemporal budget constraint of the government. Assuming a time invariant interest rate, the governmental budget constraint can be expressed as:

$$
D_{t}=(1+i) \cdot D_{t-1}+S_{t}
$$

where $D_{t}$ denotes the actual stock of real debt, $i$ stands for the nominal interest rate, $D_{t-1}$ represents the pre-existing stock of debt and $S_{t}$ is the primary (non-interest) balance, with $S_{t}<0$ representing a primary surplus. Normalizing the stock of public debt and the primary deficit by nominal GDP and solving equation (1) forward in time yields the following intertemporal budget constraint

$$
d_{T}=\left[\frac{1+i}{(1+\beta)(1+\pi)}\right]^{T} d_{0}+\sum_{t=1}^{T} s_{t}\left[\frac{1+i}{(1+\beta)(1+\pi)}\right]^{(T-t)},
$$

where $\beta$ and $\pi$ are the real growth rate and the inflation rate respectively (that for simplicity are assumed to be time invariant). Discounting equation (2) to time zero, i.e. multiplying both sides by $\left[\frac{1+i}{(1+\beta)(1+\pi)}\right]^{-T}$, and taking the limit as $T \rightarrow \infty$ yields the present value budget constraint:

$$
\lim _{T \rightarrow \infty}\left[\frac{1+i}{(1+\beta)(1+\pi)}\right]^{-T} d_{T}=d_{0}+\lim _{T \rightarrow \infty} \sum_{t=1}^{T} s_{t} \cdot\left[\frac{1+i}{(1+\beta)(1+\pi)}\right]^{-t}
$$

Fiscal sustainability for $(1+i)>(1+\beta)(1+\pi)$ requires that the government does not engage in a Ponzi scheme, where all the interest payments are covered by new debt. The no-Ponzi or transversality condition is technically stated by the fact that the 
present discounted value of the government debt-to-GDP ratio converges to zero in the limit:

$$
\lim _{T \rightarrow \infty}\left[\frac{1+i}{(1+\beta)(1+\pi)}\right]^{-T} d_{T}=0
$$

Inserting this transversality condition into equation (3) yields a formal definition for sustainability:

$$
d_{0}=-\lim _{T \rightarrow \infty} \sum_{t=1}^{T} s_{t} \cdot\left[\frac{1+i}{(1+\beta)(1+\pi)}\right]^{-t}
$$

From equation (5), a sustainable fiscal policy requires that the value of the initial debt-to-GDP ratio equals the negative present value of all future primary deficit ratios. Equation (5) is only satisfied if the transversality condition, equation (4), is fulfilled (see e.g. Ley 2010).

A large body of empirical studies exists that examines whether (4) and (5) are fulfilled. Hamilton and Flavin (1986) was an early study using a stationarity approach to test the compliance with the no-Ponzi condition. Employing annual U.S. data over the period 1960 - 1984 they find evidence for a sustainable fiscal policy in the US. Thereafter, numerous studies conducting empirical tests on the intertemporal budget constraint were published, mostly for the US but also for other countries, yielding partly different conclusions concerning the fiscal sustainability of the respective states (see e.g. Wilcox 1989, Kremers 1989, Haug 1990, Hakkio and Rush 1991 or Trehan and Walsh 1991).

These standard test procedures are conducted under the strong assumption of certainty. However, Bohn (1998) as well as Perotti (2007) emphasize that expectations and uncertainty, surrounding prospective fiscal variables, play an important role in the assessment of fiscal policy. In the presence of uncertainty an 
adequate solvency test requires a correct discount factor, which is determined by the marginal rate of substitution between consumption at time $t$ and time $t+1$, rather than the "safe interest rate". The possibility that some of the existing empirical tests rest on incorrect discount factors casts doubt on their reliability. However, since the correct discount factor is based on several assumptions about prospective states of nature that are hard to estimate, Bohn (1998) suggests the alternative concept of a fiscal reaction function ("model-based sustainability" approach i.e. MBS) to assess fiscal sustainability. In contrast to the standard empirical methods, the MBS approach tests for particular time series properties of fiscal data and does not require any assumptions about the appropriate discount factors. In addition, the MBS approach neither requires specific assumptions about the debt structure in terms of its composition nor does this approach require any particular information on the design of fiscal policy.

\section{Fiscal Reaction Functions}

The idea of Bohn's (1998) MBS approach rests on the analysis of how the primary fiscal balance (i.e. fiscal balance excluding the interest payments on public debt) reacts to variations in the sovereign debt caused by economic shocks. In such a framework, fiscal policy is considered sustainable once the government reacts systematically to a change in public debt by adjusting the primary fiscal balance. The intuition is, that if a fiscal policy is considered sustainable prior to a certain economic shock, the absence of any systematic policy reaction to this shock would cause the additionally issued debt to be uncovered by future surpluses, thus violating the no-

Ponzi condition. Therefore, the government has to react systematically to the 
extended debt-to-GDP ratio by increasing the primary surplus-to-GDP ratio, in order to maintain fiscal sustainability.

In the simplest and most common version it assumes a linear connection between the inherited debt level and the primary surplus of period $t$.

$$
s_{t}=\rho \cdot d_{t}+\mu_{t} \text {, }
$$

where $s_{t}$ is the primary surplus of period $t$ as a fraction of GDP, $d_{t}$ is the initial debt in terms of GDP, and $\mu_{t}$ is representing other influences of the primary surplus. According to Proposition 1 in Bohn (2008), if $\mu_{t}$ is bounded as a share of GDP and the present value of GDP is finite, then $\rho>0$ satisfies the economy's intertemporal budget constraint and the no-Ponzi condition. Hence, a significantly positive $\rho$ is a strong indicator for fiscal sustainability.

Using historical annual US fiscal data, Bohn (1998) finds significant response coefficients for the period 1916 - 1995 as well as for the period $1793-2003$ and thus concludes that U.S. fiscal policy has been in line with sustainability for these particular periods. Similarly, Greiner et al. (2007) investigate whether several Euroarea countries (Germany, France, Italy and Portugal) have restored their fiscal imbalance by appropriately adjusting their fiscal policy. Applying Bohn's MBS approach on annual fiscal data over the period 1960-2003 they find positive and robust response coefficients, thus concluding that fiscal policy in these European countries follows a sustainable path. 
Mendoza and Ostry (2008) apply Bohn's approach to inspect fiscal sustainability in both emerging economies and advanced economies. Analyzing annual fiscal data over the periods 1970-2005 (for industrial countries) and 19902005 (for emerging countries) to a panel of 34 emerging and 21 industrial countries, they conclude that both emerging and industrial countries operate a sustainable fiscal policy. For a very recent application see also Ghosh et al. (2013). To the best of our knowledge, none of the existing papers highlights the role of euro membership for fiscal reaction functions as will be the emphasis in the following sections.

\section{Descriptive Statistics}

Before turning to regressions we look at public debt and primary deficit ratios over time. Figure 1 and Figure 2 illustrate the development of public debt and primary deficits for all countries that currently are members of the euro area. From the mid1990s the countries now comprising the euro area pursued a policy of fiscal consolidation in order to fulfill the requirements for the start of the European Monetary Union in 1999. While during the period 1995-2006 public debt ratios and primary deficit ratios were decreasing, the financial crisis triggered a period of significant increases in deficit and debt ratios. In 2011, only five (Estonia, Finland, Luxembourg, Slovak Republic and Slovenia) out of 17 euro-area countries had a debt ratio below the $60 \%$ agreed in the Maastricht treaty. Only six (Austria, Estonia, Finland, Germany, Luxembourg and Malta) euro-area countries had a deficit below $3 \%$ of GDP. 
Figure 1: Public Debt: Time Series

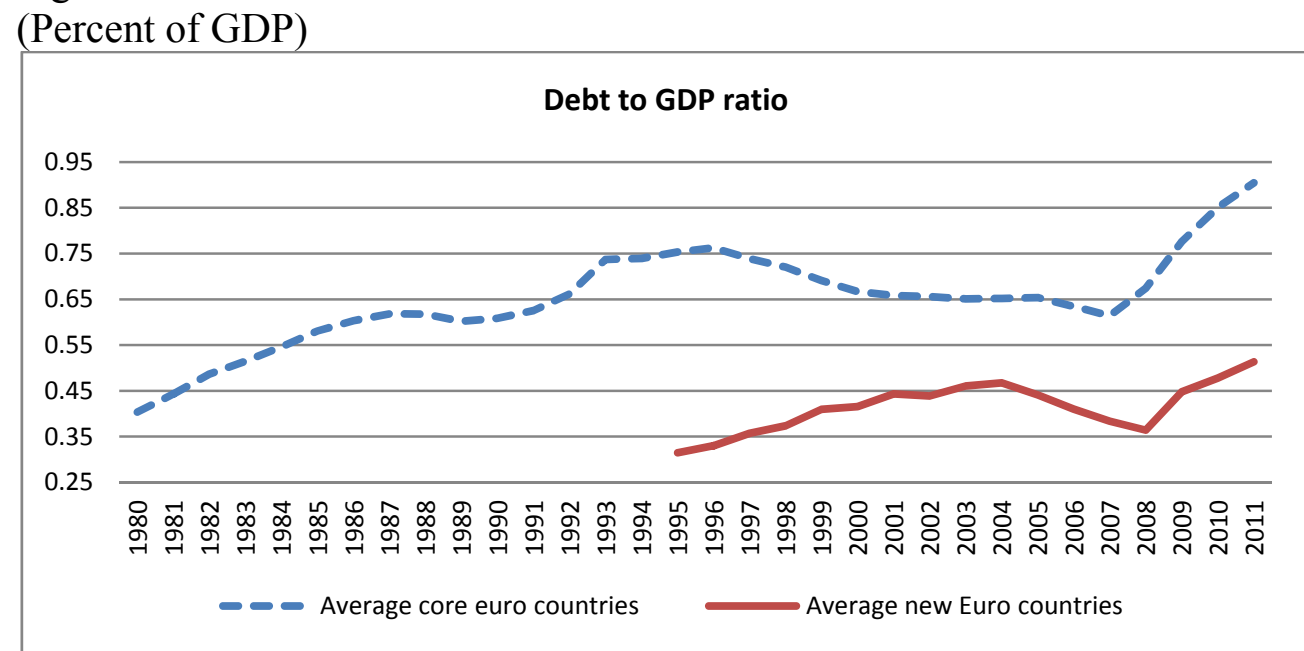

Note: Based on unweighted country averages. Core euro countries are Austria, Belgium, Finland, France, Germany, Greece, Ireland, Italy, Luxembour, Netherlands Portugal and Spain. New euro countries are Estland, Slovak Republic, Slovenia, Malta and Cyprus. Source: Own calculations based on the OECD Analytical Database

Figure 2: Primary Deficits: Time Series

(Percent of GDP)

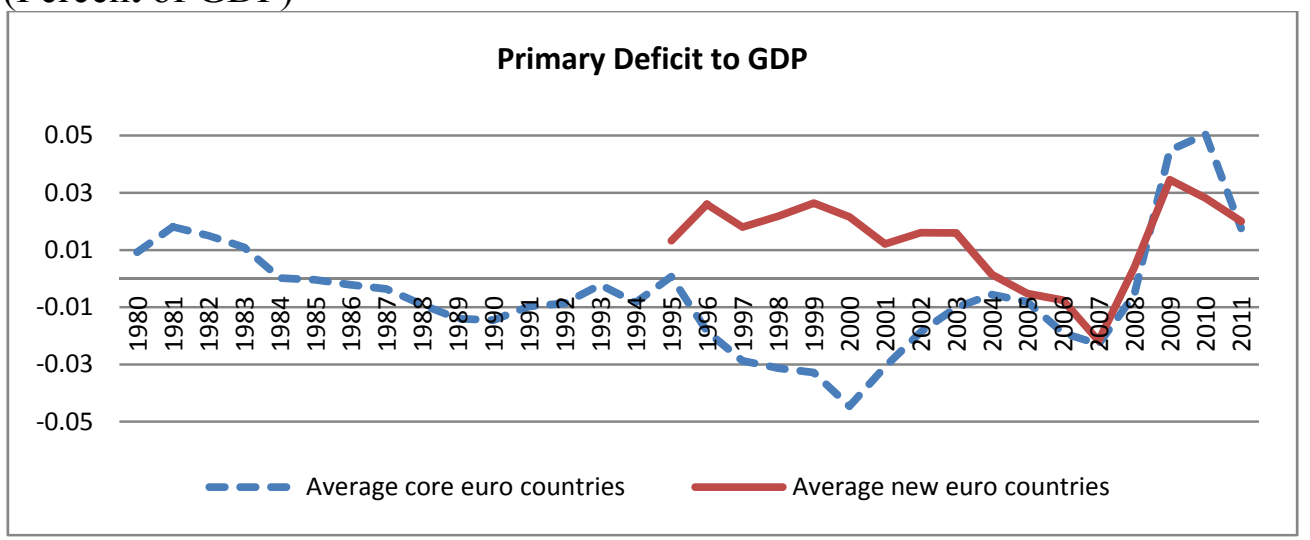

Note: Based on unweighted country averages. Core euro countries are Austria, Belgium, Finland, France, Germany, Greece, Ireland, Italy, Luxembour, Netherlands Portugal and Spain. New euro countries are Estland, Slovak Republic, Slovenia, Malta and Cyprus. Source: Own calculations based on the OECD Analytical Database and OECD Economic Outlook Database. 
Figure 3: Debt and Primary Surpluses: Cross-section
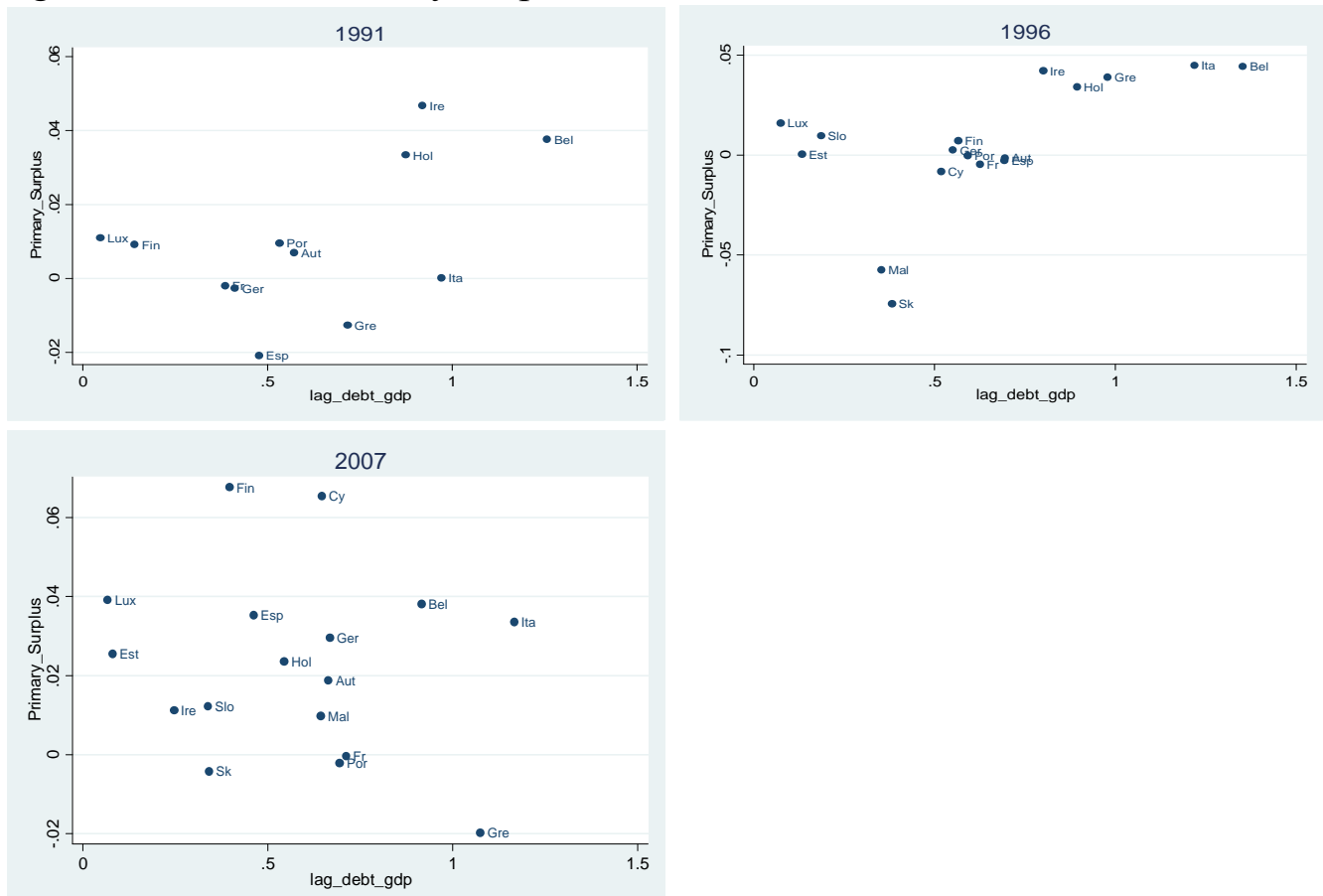

Note: Figure 3 plots the primary surplus as a share of GDP versus the inherited level of debt to GDP for the years 1991, 1996 and 2007 respectively. Source: Own calculations based on the OECD Analytical Database and OECD Economic Outlook Database.

The simple arithmetic of the intertemporal budget restriction discussed in Section 2 suggests a positive relationship between inherited debt levels and the primary surplus of countries. Figure 3 shows scatter plots of the primary balanceGDP ratio against the lagged debt GDP-ratio for selected years. 1991 represents the period before the signing of the Maastricht Treaty. 1996 is part of the aspiration period and the period during the Euro membership is covered by the figure for 2007 . The scatter plots indeed suggest that the positive correlation has become weaker over time. It will be the purpose of the next section to investigate the existence of a systematic influence of euro membership on countries' fiscal reaction functions. 


\section{$5 \quad$ Empirical Analysis of Fiscal Adjustments}

Our cross-country application of Bohn's (1998) MBS approach is based on an unbalanced panel data set for the 17 current euro-area countries during the period 1970-2011. While for most of the founding countries of the euro, data are available for the period 1970-2012, the corresponding data for some euro-area countries, in particular the eastern European countries, start later. ${ }^{2}$ Important variables are the total public debt ratio, the primary fiscal balance, real GDP, and total government expenditures. We use information from the OECD Analytical Database on general government gross financial liabilities, government deficit / surplus, real GDP at current prices, and total expenditure of general government. For the gross government interest payments we use data from the OECD Economic Outlook Database. Since fiscal data for Germany prior to reunification are not available in the OECD and IMF databases, we collect the required data from the German Federal Statistical Office. Table 2A of the Appendix contains summary statistics for the variables under consideration for the full sample period as well as the samples corresponding to period before the Maastricht Treaty, the samples corresponding to the aspiration period and the period after the Maastricht Treaty respectively.

Similar to Mendoza and Ostry (2008) we estimate a cross-country panel version of Bohn's (1998) MBS approach. We will start by examining how the primary surplus to GDP ratio in the EMU reacts to variations in the debt-to-GDP ratio by estimating variants of the equation

$$
s_{i, t}=\rho d_{i, t-1}+\alpha V_{i, t}+\varepsilon_{i, t},
$$

\footnotetext{
${ }^{2}$ Table $1 \mathrm{~A}$ in the appendix gives an overview of data availability for all countries included in our study.
} 
where $s_{i, t}$ is the primary surplus, $d_{i, t-1}$ denotes the lagged debt to GDP ratio, $V_{i, t}$ is a vector which includes a set of determinants of the primary surplus and $\varepsilon_{i, t}$ represents an error term. Following Greiner et al. (2007) we use lagged values of debt to GDP rather than actual values to avoid simultaneity problems. Depending on the model specification, the vector $V_{i, t}$ includes different regressors following the relevant literature (e.g., Bohn 1998, Mendoza and Ostry 2008).

Table 1 reports results for variants of equation (7). All regressions include country and time fixed effects; the $t$-statistics are corrected for potential heteroskedasticity and country-specific serial correlation in the residuals. Column I presents a regression that uses the lagged debt to GDP ratio as the only regressor. Column II displays the results for a specification that adds a measure of the output deviation as an explanatory variable. Among other things, it may capture the resistance against high primary surplus in times of a flat economy. Column III, following Bohn (1998), and Mendoza and Ostry (2008), adds the expenditure deviation, which has been suggested to account for shocks in expenditure needs, along with a measure of the output deviation. The variables output deviation and expenditure deviation are derived as percentage deviations of output and government expenditures from their respective trends using the Hodrick-Prescott filter and a standard smoothing parameter of $\lambda=100$. 
Table 1. Debt Sustainability Regression (1970-2011)

(dependent variable: primary surplus as share of GDP)

\begin{tabular}{c|ccc}
\hline \multicolumn{2}{c}{ I } & II & III \\
\hline debt-gdp ratio $(\rho)$ & $0.043 * * *$ & $0.046^{* * *}$ & $0.059 * * *$ \\
output deviation & $(3.53)$ & $(3.59)$ & $(3.45)$ \\
& & 0.039 & $0.334 * * *$ \\
expenditure deviation & & $(0.88)$ & $(3.32)$ \\
R2 & & & $-0.391 * * *$ \\
No. of observations & & & $(5.09)$ \\
& 0.422 & 0.431 & 0.594 \\
\hline
\end{tabular}

Note: All regressions include unreported country fixed effects and time fixed effects. The sample is unbalanced and covers years 1970-2011. t-values in parentheses are corrected for heteroskedasticity and serial autocorrelation in the errors. "*”, “**” and "***" denote significance at the 10,5 and 1 percent confidence level, respectively. output deviation and expenditure deviation are calculated from the cyclical components from the Hodrick-Prescott filter and included in percent of the trend figures.

All regressions provide evidence for a positive and statistically significant parameter $\rho$ that captures the fiscal reaction behavior. The result in column I indicates that the euro-area countries for the whole sample period reacted to a one percentage point increase in the lagged debt to GDP ratio by increasing the primary surplus to GDP ratio by 0.043 percentage points. This systematic response provides evidence for overall sustainable fiscal policies. Adding cyclical fluctuations in output to the set of explanatory variables (column II) leaves the coefficient largely unchanged ( $\rho=$ 0.046). The estimated coefficient of the output deviation is positive as expected, i.e. a good economy is good for primary surpluses, but insignificant in column II. The estimated coefficient $\rho$ is largely robust to this inclusion of our measures of the expenditure deviation and output deviation (column III). The estimates of the response coefficients in Table 1, ranging from 0.043 to 0.059 , are in line with the findings of Bohn (1998), Bohn (2008), Greiner et al. (2007), and Mendoza and Ostry (2007) for other sets of countries. They are also robust to exclusion of the crisis years 2009-2011.

In a next step, we ask whether the prudence of fiscal policies has been thwarted by euro membership and euro-area countries have changed their fiscal behavior. In particular, we are interested in the possibility that fiscal reaction 
functions differ across different periods. We may consider the time before the signing of the Maastricht Treaty (pre) as a stage during which countries were neither influenced by having a common currency, nor by the aspirations to be accepted to the common currency. In the period between signing of the Maastricht Treaty and the start of the common currency countries faced the Maastricht criteria which were important for acceptance into EMU with possibly stronger incentives for fiscal responsibility. More precisely, from 1992 we define a country to be in this aspiration period once it is also an official member of the European exchange rate mechanism, but not a euro member yet. Finally, we consider the time since full membership began (eur) as a separate time period that is of special interest. Table $3 \mathrm{~A}$ in the appendix contains the exact classification of pre and eur for each country in the sample. A plausible hypothesis may be that the attainment of a de jure irrevocable membership status has reduced the prudence of fiscal policies. This leads us to estimate variants of the equation

$s_{i, t}=\rho d_{i, t-1}+\beta_{1}$ pre $+\beta_{2}$ eur $+\beta_{3}$ pre $\cdot d_{i, t-1}+\beta_{4}$ eur $\cdot d_{i, t-1}+\alpha V_{i, t}+\varepsilon_{i, t}$,

where again $V_{i, t}$ is a vector that includes a set of determinants of the primary surplus. The dummy variable pre equals one for the time before the signing of the Maastricht Treaty and the dummy variable eur equals one since full euro membership (i.e. 1999 for most countries). In addition, pre $\cdot d_{i, t-1}\left(\right.$ eur $\left.\cdot d_{i, t-1}\right)$ represent interaction terms between the debt-to-GDP ratio in the previous period and the pre dummy (the eur dummy). Depending on the model specification, $V_{i, t}$ also includes the percentage deviation of real GDP from its trend and the percentage deviation of total government expenditures to its trend as in Table 1. As we want to test for the change in fiscal behavior within the three periods, the coefficients of interest are $\rho, \beta_{3}$ and $\beta_{4}$. The coefficient $\rho$ determines whether the primary surplus reacts systematically to variations in the lagged debt to GDP ratio in the aspiration period, which 
econometrically serves as the default period. The coefficient $\beta_{3}$ shows whether the response of the primary surplus to changes in the inherited debt to GDP ratio is different within the aspiration period and the pre-Maastricht period. The main coefficient of interest is $\beta_{4}$ that captures a possible difference between the aspiration period and the period of euro membership.

Table 2. Debt Sustainability Regressions (1970-2011) (dependent variable: primary surplus as share of GDP)

\begin{tabular}{|c|c|c|c|}
\hline & I & II & IV \\
\hline \multirow[t]{2}{*}{ debt-gdp ratio $(\rho)$} & $0.070 * * *$ & $0.072 * * *$ & $0.088 * * *$ \\
\hline & $(5.54)$ & $(5.53)$ & $(5.43)$ \\
\hline \multirow[t]{2}{*}{ pre $\left(\beta_{1}\right)$} & -0.010 & -0.009 & -0.003 \\
\hline & $(1.05)$ & $(0.93)$ & $(0.33)$ \\
\hline \multirow[t]{2}{*}{$\operatorname{eur}\left(\beta_{2}\right)$} & 0.015 & 0.012 & 0.009 \\
\hline & $(1.49)$ & $(1.26)$ & $(1.15)$ \\
\hline \multirow[t]{2}{*}{ pre_lagged_debt $\left(\beta_{3}\right)$} & $-0.070 * * *$ & $-0.070 * * *$ & $-0.063 * * *$ \\
\hline & $(5.88)$ & $(6.01)$ & (4.98) \\
\hline \multirow[t]{2}{*}{ eur_lagged_debt $\left(\beta_{4}\right)$} & $-0.026^{* *}$ & $-0.024 * *$ & $-0.022 * *$ \\
\hline & $(2.17)$ & $(2.05)$ & $(2.30)$ \\
\hline \multirow[t]{2}{*}{ output deviation } & & 0.039 & $0.323 * * *$ \\
\hline & & $(1.02)$ & $(3.51)$ \\
\hline \multirow[t]{2}{*}{ expenditure deviation } & & & $-0.358 * * *$ \\
\hline & & & $(4.52)$ \\
\hline $\mathrm{R} 2$ & 0.521 & 0.531 & 0.660 \\
\hline No. of observations & 512 & 511 & 404 \\
\hline
\end{tabular}

Note: All regressions include unreported country and time fixed effects. The sample is unbalanced and covers years 1970-2011. t-values in parentheses are corrected for heteroskedasticity and serial autocorrelation in the errors. “*”, “**” and “***” denote significance at the 10,5 and 1 percent confidence level, respectively. output deviation and expenditure deviation are calculated from the cyclical components from the Hodrick-Prescott filter and included in percent of the trend figures.

The results derived from this exercise seem to be in line with a popular view that, while governments undertook efforts to secure entry into EMU, the fiscal rules of EMU were insufficient to produce a similarly high level of fiscal prudence after countries were admitted to the euro: in all three specifications, the relevant interaction term eur_lagged_debt is negative and significant at the 5 percent level. At the same time, in all three regressions the simultaneous inclusion of the coefficients debt-gdp ratio and eur_lagged_debt continues to yield a significantly positive reaction to debt 
shocks as the addition of $\rho$ and $\beta_{4}$ coefficients is positive and statistically significant. This can be interpreted in favor of an overall sustainable policy for the period since 1999. This is in contrast to what can be said for the pre-Maastricht period; the addition of debt-gdp ratio and pre_lagged_debt leads to an overall effect indistinguishable from zero according to columns I and II, and to a small insignificant overall effect (0.016) according to column III.

Fiscal reactions of euro members to debt shocks, according to Table 2, have been less pronounced than in the period before euro membership. While this may conform to popular beliefs, there may be doubt about the robustness of this result. One possible reason for such doubt is the inclusion of the crisis years 2009-2011, which may have a decisive influence on the results due to huge deficits. Another issue is that the regressions presented in Table 2 ignore country heterogeneity. While the short experience with fiscal policies in the euro era suggests using panel data, the results reflect the fiscal reactions of quite heterogeneous countries. A particular concern may be related to Greece. While the data used in our regressions are based on revised data, the political process in Greece had to rely on cross misstatements of the budget deficit.

To investigate the robustness of our results, Table 3 presents results based on the omission of the crisis years 2009-2011. As can be seen, this severely reduces the significance of the interaction term eur_lagged_debt, which turns insignificant in two out of three regressions and is only significant at the ten percent level in column III. While this reduced significance could result from a reduction in the relevant observations for euro members, it may also be seen as a warning against premature conclusions from Table 2. 
Table 3. Debt Sustainability Regression (1970-2008)

(dependent variable: primary surplus as share of GDP)

\begin{tabular}{c|ccc}
\hline & I & II & III \\
\hline debt-gdp ratio $(\rho)$ & $0.066^{* * *}$ & $0.067^{* * *}$ & $0.075^{* * *}$ \\
pre $\left(\beta_{1}\right)$ & $(5.62)$ & $(5.64)$ & $(6.71)$ \\
& -0.001 & -0.001 & 0.005 \\
eur $\left(\beta_{2}\right)$ & $(0.12)$ & $(0.08)$ & $(0.73)$ \\
& 0.008 & 0.007 & 0.001 \\
pre_lagged_debt $\left(\beta_{3}\right)$ & $(0.77)$ & $(0.67)$ & $(0.15)$ \\
& $-0.072^{* * *}$ & $-0.072^{* * *}$ & $-0.064^{* * *}$ \\
eur_lagged_debt $\left(\beta_{4}\right)$ & $(5.94)$ & $(5.97)$ & $(5.41)$ \\
& -0.022 & -0.022 & $-0.023^{* *}$ \\
output deviation & $(1.78)$ & $(1.78)$ & $(2.52)$ \\
& & 0.025 & $0.310^{* * *}$ \\
expenditure deviation & & $(0.95)$ & $(6.38)$ \\
R2 & & & $-0.304^{* * *}$ \\
No. of observations & & & $(6.62)$ \\
& 0.575 & 0.580 & 0.690 \\
& 461 & 461 & 354 \\
\hline
\end{tabular}

Note: All regressions include unreported country and time fixed effects. The sample is unbalanced and covers years 1970-2008. t-values in parentheses are corrected for heteroskedasticity and serial autocorrelation in the errors. "*”, “**” and “***” denote significance at the 10,5 and 1 percent confidence level, respectively. output deviation and expenditure deviation are calculated from the cyclical components from the Hodrick-Prescott filter and included in percent of the trend figures.

As noted, another issue is that the results that suggest a reduced fiscal reaction to debt shocks may arise from heterogeneity or may rest only on a small subgroup of countries. We therefore ran robustness checks by leaving out one country after the other in turn. Results are reported in Table 4 which is based on regressions using years 1970-2011. Again, we are particularly interested in the robustness of the negative eur_lagged_debt coefficient. We find that the results are pretty stable for all exclusions except one. When leaving Greece out of the sample, the magnitude of the coefficient drops by more than two-thirds and its significance is lost. The result of the regressions in Table 2, which suggested euro membership has significantly decreased fiscal reactions to debt, seems to be very strongly based on the change in Greek fiscal policy compared to pre-euro years.

There are two potential explanations that come to mind. A first possibility is that the data we are using is not the data that was available to Greek parliament and 
the wider public at the time budgets were drafted. The extensive fabrication of Greek budget deficit numbers has been extensively documented. ${ }^{3}$ Rerunning regression III of Table 3 with the initially reported Greek deficit figures for the years 2000-2008 using the data provided by European Commission (2010) implies that eur_lagged_debt is still estimated to be significantly negative at the 6 percent level.

Table 4. Debt Sustainability Regressions with Country Exclusions (1970-2011)

\begin{tabular}{|c|c|c|c|c|c|c|c|c|}
\hline \multirow{2}{*}{$\begin{array}{l}\text { Excluded } \\
\text { Country }\end{array}$} & \multirow{2}{*}{$\begin{array}{c}\text { debt-gdp- } \\
\text { ratio }\end{array}$} & \multicolumn{6}{|c|}{ (dependent variable: primary surplus as share of GDP) } & \multirow[b]{2}{*}{ Observations } \\
\hline & & t-statistic & pre_lag_debt & t-statistic & eur_lag_debt & t-statistic & adj. R2 & \\
\hline Austria & $0.086^{* * *}$ & $(5.36)$ & $-0.060 * * *$ & $(-4.66)$ & $-0.022 * *$ & $(-2.31)$ & 0.688 & 368 \\
\hline Belgium & $0.110 * * *$ & $(5.44)$ & $-0.085 * * *$ & $(-6.73)$ & $-0.043 * * *$ & $(-3.83)$ & 0.671 & 372 \\
\hline Cyprus & $0.088 * * *$ & $(5.32)$ & $-0.064 * * *$ & $(-4.86)$ & $-0.023 * *$ & $(-2.34)$ & 0.656 & 388 \\
\hline Estonia & $0.092 * * *$ & $(5.55)$ & $-0.068 * * *$ & $(-4.94)$ & $-0.025 * *$ & $(-2.38)$ & 0.673 & 388 \\
\hline Finland & $0.083 * * *$ & $(4.98)$ & $-0.052 * * *$ & $(-3.95)$ & $-0.018^{*}$ & $(-1.86)$ & 0.644 & 367 \\
\hline France & $0.092 * * *$ & (5.59) & $-0.056^{* * *}$ & $(-4.31)$ & $-0.021 * *$ & $(-2.11)$ & 0.668 & 371 \\
\hline Germany & $0.084 * * *$ & $(5.32)$ & $-0.063 * * *$ & $(-4.86)$ & $-0.021 * *$ & $(-2.22)$ & 0.667 & 383 \\
\hline Greece & $0.088^{* * *}$ & $(5.27)$ & $-0.058 * * *$ & $(-4.73)$ & -0.006 & $(-0.71)$ & 0.668 & 380 \\
\hline Ireland & $0.060 * * *$ & (4.19) & $-0.064 * * *$ & $(-5.12)$ & $-0.025 * * *$ & $(-2.75)$ & 0.701 & 378 \\
\hline Italy & $0.083^{* * *}$ & $(4.80)$ & $-0.058 * * *$ & $(-3.97)$ & $-0.021^{*}$ & $(-1.79)$ & 0.655 & 372 \\
\hline Luxembourg & $0.094 * * *$ & $(5.51)$ & $-0.071 * * *$ & $(-4.78)$ & $-0.029 * *$ & $(-2.26)$ & 0.655 & 382 \\
\hline Malta & $0.087 * * *$ & $(5.38)$ & $-0.063 * * *$ & $(-4.88)$ & $-0.023 * *$ & $(-2.35)$ & 0.662 & 392 \\
\hline Netherlands & $0.090 * * *$ & $(5.36)$ & $-0.064 * * *$ & $(-4.98)$ & $-0.023 * *$ & $(-2.31)$ & 0.654 & 387 \\
\hline Portugal & $0.089^{* * *}$ & $(5.47)$ & $-0.064 * * *$ & $(-5.00)$ & $-0.023 * *$ & $(-2.36)$ & 0.654 & 387 \\
\hline Slovak Rep. & $0.086^{* * *}$ & $(5.30)$ & $-0.063 * * *$ & $(-4.92)$ & $-0.020 * *$ & $(-2.12)$ & 0.641 & 388 \\
\hline Slovenia & $0.089 * * *$ & $(5.48)$ & $-0.063 * * *$ & $(-4.88)$ & $-0.024 * *$ & $(-2.38)$ & 0.657 & 388 \\
\hline Spain & $0.089 * * *$ & $(5.36)$ & $-0.067 * * *$ & $(-5.21)$ & $-0.021 * *$ & $(-2.17)$ & 0.651 & 373 \\
\hline
\end{tabular}

Note: All regressions include time and country fixed effects. The sample is unbalanced and covers years 1970-2011. t-values in parentheses are corrected for heteroskedasticity and serial autocorrelation in the errors. "**, “**” and “***" denote significance at the 10,5 and 1 percent confidence level, respectively. While the regression includes output deviation, expenditure deviation, pre and eur, Table 4 does not report the respective results. output deviation and expenditure deviation are calculated from the cyclical components from the Hodrick-Prescott filter and included in percent of the trend figures.

Another possible explanation is that due to the weak political governance, Greece was particularly prone to consume the increased fiscal leeway

\footnotetext{
${ }^{3}$ See, e.g., European Commission (2010). The doctoring of deficit figures also led to comparatively large stock-flow adjustments which are needed when the development of the debt stock cannot be explained by accumulated deficits. See Moutos and Tsitsikas (2010).
} 
from reduced interest rates after euro accession, blocking out the need to react to increases in debt levels.

Table 5. Debt Sustainability Regressions with Country Exclusions (1970-2008)

\begin{tabular}{|c|c|c|c|c|c|c|c|c|}
\hline \multirow{2}{*}{$\begin{array}{l}\text { Excluded } \\
\text { Country }\end{array}$} & \multicolumn{8}{|c|}{ (dependent variable: primary surplus as share of GDP) } \\
\hline & debt-gdp-ratio & $\begin{array}{c}\mathrm{t}- \\
\text { statistic }\end{array}$ & pre_lag_debt & $\begin{array}{c}\mathrm{t}- \\
\text { statistic }\end{array}$ & eur_lag_debt & $\begin{array}{c}\mathrm{t}- \\
\text { statistic } \\
\end{array}$ & $\begin{array}{l}\text { adj. } \\
\text { R }\end{array}$ & Observations \\
\hline Austria & $0.073 * * *$ & $(6.61)$ & $-0.060 * * *$ & $(-5.09)$ & $-0.024 * * *$ & $(-2.63)$ & 0.728 & 312 \\
\hline Belgium & $0.089 * * *$ & $(8.20)$ & $-0.085 * * *$ & $(-8.19)$ & $-0.041 * * *$ & $(-4.17)$ & 0.720 & 325 \\
\hline Cyprus & $0.075^{* * *}$ & $(6.61)$ & $-0.063 * * *$ & $(-5.18)$ & $-0.023 * *$ & $(-2.51)$ & 0.691 & 341 \\
\hline Estonia & $0.076^{* * *}$ & $(6.51)$ & $-0.065 * * *$ & $(-5.10)$ & $-0.024 * *$ & $(-2.53)$ & 0.692 & 341 \\
\hline Finland & $0.070 * * *$ & $(6.55)$ & $-0.051 * * *$ & $(-4.35)$ & $-0.018 * *$ & $(-2.13)$ & 0.693 & 320 \\
\hline France & $0.078 * * *$ & (6.93) & $-0.057 * * *$ & $(-4.72)$ & $-0.022 * *$ & $(-2.40)$ & 0.705 & 324 \\
\hline Germany & $0.074 * * *$ & $(6.41)$ & $-0.064 * * *$ & $(-5.38)$ & $-0.023 * *$ & $(-2.50)$ & 0.690 & 336 \\
\hline Greece & $0.072 * * *$ & (6.67) & $-0.059 * * *$ & $(-5.17)$ & -0.011 & $(-1.24)$ & 0.714 & 333 \\
\hline Ireland & $0.064 * * *$ & (3.84) & $-0.061 * * *$ & $(-4.92)$ & $-0.025 * * *$ & $(-2.63)$ & 0.689 & 330 \\
\hline Italy & $0.068 * * *$ & (5.88) & $-0.058 * * *$ & $(-4.42)$ & -0.017 & $(-1.59)$ & 0.683 & 325 \\
\hline Luxembourg & $0.083 * * *$ & $(6.63)$ & $-0.073 * * *$ & $(-5.42)$ & $-0.034 * * *$ & $(-2.79)$ & 0.691 & 335 \\
\hline Malta & $0.074 * * *$ & $(6.55)$ & $-0.064 * * *$ & $(-5.32)$ & $-0.023 * *$ & $(-2.51)$ & 0.688 & 345 \\
\hline Netherlands & $0.076^{* * *}$ & $(6.63)$ & $-0.065 * * *$ & $(-5.42)$ & $-0.024 * *$ & $(-2.55)$ & 0.689 & 340 \\
\hline Portugal & $0.076^{* * *}$ & $(6.689$ & $-0.065 * * *$ & $(-5.44)$ & $-0.024 * *$ & $(-2.55)$ & 0.692 & 340 \\
\hline Slovak Rep. & $0.073 * * *$ & $(6.46)$ & $-0.064 * * *$ & $(-5.41)$ & $-0.023 * *$ & $(-2.47)$ & 0.672 & 341 \\
\hline Slovenia & $0.075 * * *$ & (6.64) & $-0.064 * * *$ & $(-5.38)$ & $-0.024 * *$ & $(-2.52)$ & 0.691 & 341 \\
\hline Spain & $0.077 * * *$ & $(6.83)$ & $-0.069 * * *$ & $(-5.66)$ & $-0.021 * *$ & $(-2.29)$ & 0.696 & 326 \\
\hline
\end{tabular}

Note: All regressions include time and country fixed effects. The sample is unbalanced and covers years 1970-2008. t-values in parentheses are corrected for heteroskedasticity and serial autocorrelation in the errors. "**", “**” and "**** denote significance at the 10,5 and 1 percent confidence level, respectively. While the regression includes output deviation, expenditure deviation, pre and eur, Table 5 does not report the respective results. output deviation and expenditure deviation are calculated from the cyclical components from the Hodrick-Prescott filter and included in percent of the trend figures.

It is worth emphasizing that, unlike the exclusion of Greece, other exclusions have only mild effects. Dropping Italy increases the standard error of eur_lagged_debt and the significance level of this variable is consequently somewhat reduced. However, the point estimate is largely unaffected in this case. A country that has some importance for the size of the estimated coefficient of eur_lagged_debt is 
Belgium. Dropping Belgium from the sample, but keeping Greece, results in a larger differential effect compared to the aspiration period.

Table 5 presents evidence on the same robustness test using years up to 2008 only. Again, the exclusion of Greece leads to eur_lagged_debt becoming insignficant. Excluding the years after 2008, the same now applies to exclusion of Italy, but the loss in significance is accompanied by a somewhat smaller change in the point estimate than in the case of excluding Greece.

Table 6. Debt Sustainability Regression for individual Countries (1970-2011) (dependent variable: primary surplus as share of GDP)

\begin{tabular}{c|cccccc}
\hline \hline & $\begin{array}{l}\text { debt-gdp } \\
\text { ratio }\end{array}$ & $\mathrm{t}$-value & pre_lagged_debt & t-value & eur_lagged_debt & t-value \\
\hline Country & 0.052 & 0.53 & -0.069 & 0.66 & -0.126 & 0.91 \\
Austria & -0.077 & 0.41 & 0.153 & 0.81 & 0.313 & 1.63 \\
Belgium & $-0.22^{* *}$ & 3.14 & $0.278^{* *}$ & 3.05 & $0.436^{* * *}$ & 6.51 \\
Cyprus & $0.115^{* * *}$ & 2.74 & $-0.402^{* * *}$ & 3.69 & 0.061 & 0.39 \\
Finland & $0.119^{* * *}$ & 4.10 & -0.145 & 1.71 & $-0.26^{* * *}$ & 4.91 \\
France & 0.079 & 0.88 & $0.14 *$ & 1.73 & -0.091 & 0.70 \\
Germany & $0.194^{* * *}$ & 10.21 & 0.051 & 0.33 & $-0.388^{* * *}$ & 5.97 \\
Greece & $-0.151^{* *}$ & 2.80 & 0.151 & 0.88 & 0.04 & 0.09 \\
Ireland & $0.151^{* * *}$ & 7.95 & $-0.073^{* * *}$ & 2.92 & 0.133 & 1.45 \\
Italy & $0.941^{* * *}$ & 2.81 & $-0.892^{* *}$ & 2.60 & $-1.159 * * *$ & 3.59 \\
Luxembourg & -0.025 & 0.27 & 0.156 & 1.79 & 0.107 & 1.08 \\
Malta & 0.02 & 0.11 & 0.013 & 0.07 & 0.216 & 1.03 \\
Netherlands & $0.228^{* * *}$ & 3.35 & -0.052 & 0.67 & $-0.252^{* *}$ & 2.45 \\
Portugal & $0.275^{* * *}$ & 5.00 & -0.103 & 1.63 & $0.251^{*}$ & 1.77 \\
Spain & & & & & \\
\hline
\end{tabular}

Note: All regressions include a constant. t-values in parentheses are corrected for heteroskedasticity and serial autocorrelation in the errors. "*”, “**” and “***" denote significance at the 10, 5 and 1 percent confidence level, respectively. While the regression includes output deviation, expenditure deviation, pre and eur, Table 6 does not report the respective results. output deviation and expenditure deviation are calculated from the cyclical components from the Hodrick-Prescott filter and included in percent of the trend figures. The shaded rows mark those countries with a significantly negative estimate for eur_lagged_debt.

The sensitivity of the results to exclusion of countries suggests looking at all individual country's reaction functions to check for further country particularities. Table 6 provides the relevant results for the panel from 1970-2011. In total we find four countries in the sample that have a significantly negative coefficient for eur_lagged_debt. Apart from low-debt Luxembourg, these countries are France, 
Greece, and Portugal. ${ }^{4}$ Belgium has a large positive coefficient, but it is insignificant. The results from Estonia, Slovenia, Cyprus and Malta are reported, but due to their very recent euro membership these countries have only very few observations for which eur equals one and no stark conclusions should be drawn from their coefficient for eur_lagged_debt, especially given that these observations are almost exclusively from crisis years.

While Greece, Portugal and France have significantly negative coefficients for eur_lagged_debt, in all three cases the fiscal reaction coefficients for the aspiration period (debt-gdp ratio) has been very large. The coefficients estimated for pre_lagged_debt indicate that the fiscal reaction functions in the aspiration period for France, Greece and also, at least to some extent, for Portugal have been much more responsive to the debt level than in the pre-Maastricht period. Here the individual country results suggest that the efforts were not maintained after acceptance into EMU.

\section{Conclusions}

In this study we made use of fiscal reaction functions, which capture the budgetary reactions to countries' debt levels, to evaluate debt sustainability. Our consideration of different regimes (pre-Maastricht, aspiration period, EMU membership) has shown no clear evidence for a systematic reduction in fiscal prudence. While a panel regression for all Euro member countries suggests such a reduction has taken place, this result is not robust to the exclusion of a single country (Greece) and to the exclusion of crisis years. At the same time, individual country regressions suggest that for a group of three highly indebted countries (France,

\footnotetext{
${ }^{4}$ We have also performed individual regressions for years up to 2008. In this case, pre_lagged_debt is (weakly) significant and negative only for two countries (Portugal and France), but given the few observations per country with eur $=1$ these results are not reported.
} 
Greece, and Portugal) the strong reactions of primary deficits to changes in debt levels prior to accession to EMU could not be preserved within EMU.

Clearly, the analysis of fiscal reaction functions, like other statistical measures, is just one tool among several to gauge the prudence of fiscal policies. As the European debt crisis suggests, many aspects are important for the overall evaluation of a country's debt sustainability. Nevertheless, the exercise sheds light on the overall deficit incentives within EMU and provides additional evidence for the very special character of Greece's budget policy after EMU accession.

According to our analysis of fiscal reaction functions, the reduction of fiscal prudence is not a general feature of the first years of EMU. A strong caveat applies. Our results do not imply that fiscal policies are necessarily commensurate with a currency union. Notwithstanding our analysis, countries may have been admitted with too large debt levels. Membership in a currency union may even require lower debt levels as countries lose monetary policy as a means to handle public debt and competitiveness problems. 


\section{References}

Bohn, Henning (1998), "The behavior of U.S. public debt and deficits", Quarterly Journal of Economics 113, 949-963. , 2008, "The sustainability of fiscal policy in the United States", in: Reinhard Neck and Jan-Egbert Sturm (eds.), Sustainability of public debt, MIT Press, Cambridge, 15-49.

European Commission (2010), Report on Greek government deficit and debt statistics, COM(2010) 1 final.

Ghosh, Atish R., Kim, Jun I., Mendoza, Enrique G., Ostry, Jonathan D., and Mahvash S. Qureshi (2013), "Fiscal fatigue, fiscal space and debt sustainability in advanced economies", Economic Journal 123, F2-F30.

Greiner, Alfred, Koeller, Uwe and Semmler, Willi (2007), "Debt sustainability in the European Monetary Union: Theory and empirical evidence for selected countries", Oxford University Press, Oxford Economic Papers 59, 194-218.

Hakkio, Craig and Rush, Mark (1991), "Is the budget deficit "too large?"”. Economic Inquiry 29, 429-445.

Hamilton, James D. and Flavin, Marjorie A. (1986), "On the limitations of government borrowing: A framework for empirical testing", American Economic Review 76, 808-19.

Haug, Alfred (1990), "Cointegration and government borrowing constraints: Evidence for the United States", Journal of Business and Economic Statistics 9, 97-101.

IMF (2011), Fiscal monitor: Addressing fiscal challenges to reduce economic risks, Washington, September 2011.

Kremers, Jeroen J.M. (1989), "U.S. federal indebtedness and the conduct of fiscal policy", Journal of Monetary Economics 23, 219-238.

Ley, Eduardo, 2010, "Fiscal (and external) sustainability", Economic Policy and Debt Department, PREM, The World Bank, Washington.

Mendoza, Enrique G. and Ostry, Jonathan D. (2008), "International evidence on fiscal solvency: Is fiscal policy 'responsible'?", Journal of Monetary Economics 55, 1081-1093

Moutos, Thomas and Tsitsakias, Cristos (2010), "Whither public interest. The case of Greece's public finances", FinanzArchiv/Public Finance Analysis 66, 170-206.

Perotti, Roberto, (2007), "Fiscal Policy in Developing Countries: A Framework and Some Questions", Policy Research Working Paper No. 4365, World Bank, Washington.

Trehan, Bharat and Walsh, Carl (1991), "Testing intertemporal budget constraints: Theory and applications to U.S. federal budget and current account deficits", Journal of Money, Credit and Banking 23, 206-223.

Wilcox, David (1989), "The sustainability of government deficits: Implications of the present-value borrowing constraint”, Journal of Money, Credit and Banking 21, 291-306. 


\section{Appendix}

Table 1A. Data availability

$\begin{array}{cccccc}\text { Country } & \text { Debt to GDP ratio } & \text { Primary balance to GDP } & \text { real GDP } & \text { Unemployment } & \begin{array}{c}\text { Variable } \\ \text { total government } \\ \text { expenditure to GDP }\end{array} \\ & & & & 1976-2011 \\ \text { Austria } & 1970-2011 & 1970-2011 & 1970-2011 & 1970-2011 & 1980-2011 \\ \text { Belgium } & 1970-2011 & 1970-2011 & 1970-2011 & 1970-2011 & 1995-2011 \\ \text { Estonia } & 1995-2011 & 1995-2011 & 1995-2011 & 1993-2011 & 1975-2011 \\ \text { Finland } & 1970-2011 & 1970-2011 & 1970-2011 & 1970-2011 & 1978-2011 \\ \text { France } & 1970-2011 & 1978-2011 & 1970-2011 & 1970-2011 & 1991-2011 \\ \text { Germany } & 1970-2011 & 1974-2011 & 1970-2011 & 1970-2011 & 1980-2011 \\ \text { Greece } & 1980-2011 & 1988-2011 & 1995-2011 & 1995-2011 & 1980-2011 \\ \text { Ireland } & 1970-2011 & 1985-2011 & 1970-2011 & 1989-2011 & 1980-2011 \\ \text { Italy } & 1970-2011 & 1970-2011 & 1970-2011 & 1970-2011 & 1990-2011 \\ \text { Luxembourg } & 1970-2011 & 1970-2011 & 1970-2011 & 1970-2011 & 1995-2011 \\ \text { Netherlands } & 1970-2011 & 1970-2011 & 1970-2011 & 1970-2011 & 1995-2011 \\ \text { Portugal } & 1973-2011 & 1977-2011 & 1970-2011 & 1970-2011 & 1995-2011 \\ \text { Slovak Republic } & 1995-2011 & 1995-2011 & 1990-2011 & 1994-2011 & 1995-2011 \\ \text { Slovenia } & 1995-2011 & 1995-2011 & 1995-2011 & 1992-2011 & 1980-2011 \\ \text { Spain } & 1980-2011 & 1980-2011 & 1970-2011 & 1977-2011 & 1995-2011 \\ \text { Cyprus } & 1995-2011 & 1995-2011 & 1970-2011 & 1995-2011 & 2000-2011 \\ \text { Malta } & 1995-2011 & 1995-2011 & 1970-2011 & 1990-2011 & \end{array}$


Table A2. Period Classification by Country

Pre Maastricht Treaty

\begin{tabular}{cccc} 
Country & $\begin{array}{c}\text { Pre Maastricht Treaty } \\
(\text { pre }=1)\end{array}$ & Aspiration period & $\begin{array}{c}\text { Euro Membership } \\
(\text { eur }=1)\end{array}$ \\
\hline Austria & $1970-1991$ & $1992-1998$ & $1999-2011$ \\
Belgium & $1970-1991$ & $1992-1998$ & $1999-2011$ \\
Estonia & $1995-2003$ & $2004-2010$ & 2011 \\
Finland & $1970-1991$ & $1992-1998$ & $1999-2011$ \\
France & $1978-1991$ & $1992-1998$ & $1999-2011$ \\
Germany & $1974-1991$ & $1992-1998$ & $1999-2011$ \\
Greece & $1988-1991$ & $1992-2000$ & $2001-2011$ \\
Ireland & $1985-1991$ & $1992-1998$ & $1999-2011$ \\
Italy & $1970-1991$ & $1992-1998$ & $1999-2011$ \\
Luxembourg & $1970-1991$ & $1992-1998$ & $1999-2011$ \\
Netherlands & $1970-1991$ & $1992-1998$ & $1999-2011$ \\
Portugal & $1977-1991$ & $1992-1998$ & $1999-2011$ \\
Slovak Republic & $1995-2004$ & $2005-2008$ & $2009-2011$ \\
Slovenia & $1995-2003$ & $2004-2006$ & $2007-2011$ \\
Spain & $1980-1991$ & $1992-1998$ & $1999-2011$ \\
Cyprus & $1995-2004$ & $2005-2007$ & $2008-2011$ \\
Malta & $1995-2004$ & $2005-2007$ & $2008-2011$ \\
\hline
\end{tabular}


Table A3 Summary Statistics

\begin{tabular}{lccccc}
\hline Variable & Obs. & Mean & SD & Min & Max \\
\hline Primary Surplus & 498 & 0.0117056 & 0.0590181 & -0.2802633 & 0.2639207 \\
lagged debt to GDP & 494 & 0.6112865 & 0.3277643 & 0.061 & 1.700068 \\
real GDP & 646 & $2.93 \mathrm{E}+05$ & $4.98 \mathrm{E}+05$ & 0.245014 & $2.48 \mathrm{E}+06$ \\
Government expenditure to GDP & 440 & 0.4621246 & 0.0636362 & 0.27655 & 0.6678635 \\
Unemployment rate & 575 & 0.0737983 & 0.0425735 & 0.0001501 & 0.2529919 \\
\hline
\end{tabular}

Before Maastricht Treaty

\begin{tabular}{lccccc}
\hline Before Maastricht Treaty \\
\hline Variable & Obs. & Mean & SD & Min & Max \\
\hline Primary Surplus & 221 & -0.0022736 & 0.0372469 & -0.0822298 & 0.2176089 \\
lagged debt to GDP & 201 & 0.4879915 & 0.2711116 & 0.0799428 & 1.257202 \\
real GDP & 367 & 133085.9 & 251839.7 & 0.245014 & 1534600 \\
Government expenditure to GDP & 153 & 0.452921 & 0.0655769 & 0.27655 & 0.6 \\
Unemployment rate & 269 & 0.0608128 & 0.0406273 & 0.0001501 & 0.1930314 \\
\hline
\end{tabular}

Aspiration period

\begin{tabular}{lccccc}
\multicolumn{7}{c}{ Aspiration period } \\
\hline Variable & Obs. & Mean & SD & Min & Max \\
\hline Primary Surplus & 103 & 0.027195 & 0.0614806 & -0.058903 & 0.2411876 \\
lagged debt to GDP & 90 & 0.6755618 & 0.3485286 & 0.0731141 & 1.406451 \\
real GDP & 106 & 366159.7 & 519575.6 & 4.81723 & 1959700 \\
Government expenditure to GDP & 100 & 0.469983 & 0.072431 & 0.3360032 & 0.6486522 \\
Unemployment rate & 103 & 0.0923681 & 0.0429845 & 0.0137625 & 0.1910761 \\
\hline
\end{tabular}

After Maastricht Treaty

\begin{tabular}{lrrrrr}
\hline Variable & Obs. & \multicolumn{1}{c}{ Mean } & SD & Min & Max \\
\hline Primary Surplus & 174 & 0.0202917 & 0.0744782 & -0.2802633 & 0.2639207 \\
lagged debt to GDP & 203 & 0.7048703 & 0.3318579 & 0.061 & 1.700068 \\
real GDP & 173 & 587234.1 & 695331.2 & 5.81083 & 2476800 \\
Government expenditure to GDP & 187 & 0.4654526 & 0.0560109 & 0.3118289 & 0.6678635 \\
Unemployment rate & 203 & 0.0815834 & 0.0395757 & 0.0223295 & 0.2529919 \\
\hline
\end{tabular}

